The total number of overseas students in the United Kingdom is estimated at about 47,000 , and during the year the Council met on arrival 8,137 students as well as 1,299 United Nations' Fellows, Colombo Plan trainees, etc., who were assisted to find accommodation. Permanent accommodation in lodgings was found for 3,417 students, and for 405 in Council residences, and temporary accommodation for 5,005 while on study visits, etc., apart from transit or temporary accommodation in lodgings or Council residences for many more. Some 9,878 students enrolled as members of Council Centres during $1959,2,736$ attended vacation courses of 7-I5 days, 1,481 week-end courses, and 9,554 halfday or full-day study visits to factories, museums. etc.

\title{
A SCIENCE PLANNING BOARD
}

$\mathrm{T}$ HE proposal that the Government should set up a Scientific and Technical Planning Board to give "better direction to our scientific effort" is one of the recommendations for immediate action by the Association of Scientific Workers in a policy statement, "Science and Education"*.

The statement declares that, "given an adequate structure there is no reason whatever to fear a shortage of suitable people for higher education in science and engineering and teaching. Considerable untapped resources exist". The number of women in British technical colleges is very small compared with men. This difference is by no means due to innate intelligence or leanings, but largely to social customs reflected in school policies exacerbated by the desperate shortage of science teachers in girls' schools.

The Association's statement lists five objectives : to make science a central subject throughout the school lives of all children; to expand considerably the provision of educational opportunities for children beyond the age of fifteen; to overcome the critical shortage of science and mathematics teachers; to * Association of Scientifte Workers. Science and Education : a
Policy Statement by the Association of Scientifle Workers. Pp. 16. (London: Association of Scientific Workers, 1960.) is. achieve a larger annual output of scientists and engineers than the present Government's targets, as soon as possible; to raise considerably the annual output of technicians of all kinds.

The report states that the first and most fundamental need is to provide more science teachers in schools and in technical colleges, training colleges and universities-and the most acute need is in schools. The only permanent solution to a shortage is to raise the salaries of teachers. The Association believes that "the immediate critical shortage" could be alleviated by a government-led national programme of secondment or release of scientists and mathematicians from the Civil Service (including the defence departments), nationalized industries and universities to teach in schools while the 'bulge' passes through, and a national drive to bring more married women back into teaching.

Proposals are also made to have at least four, and preferably six, new university institutions before the end of the 1960's ; to expand the work of the technical colleges; to improve conditions of service of technicians in higher educational establishments; to assist more students to train to be scientists ; and to make the fullest possible use of trained scientists, technologists and technicians.

\section{TOBACCO SMOKE RESEARCH}

$\mathrm{T}$ HE Tobacco Manufacturers' Standing Committee has as a declared aim the assistance of research into questions concerned with the relationship between smoking and health. That this object is being fulfilled is evident from its report for the year ended. May 31, 1960, which summarizes investi. gations carried out during the year under the auspices of the Committee or with its financial support, including research into factors affecting smoking habits, the biological activity of tobacco smoke, factors affecting the incidence of lung cancer and certain other diseases and physiological and psychological aspects of smoking*. In addition to supporting these activities, the Committee has also made financial grants to the Medical Research Council and to the Institute of Cancer Research, Royal Cancer Hospital, London, for research into causes of lung cancer and into tumour viruses.

Fractions of cigarette smoke condensate prepared in the laboratories of the Committee have been found

* Tobacco Manufacturers' Standing Committee. Report for the Year ended 31st May, 1960. Pp. 11. (London: Tobacco Manufacturers' Standing Committee, 1980.

† Tobacco Manufacturers' Standing Committee. Research Papers, No. 3: The Constituents of Tobaceo Smoke, an Annotated Bibliography. First Supplement. Edited by $\mathcal{H}$. R. Bentley and E. G. N. Berry. Pp. $1+25$. (London: Tobacco Manufacturers' Standing
Committee, 1960.) by several workers to have carcinogenic or tumourpromoting properties, but as the report points out, these results, obtained by application of smoke fractions to animal tissues, are not necessarily reliable guides to the possible response of human lung tissue to tobacco smoke.

Some of the investigations supported by the Committee have been stimulated by the suggestion of Sir Ronald Fisher that smoking habits may be influenced by genetic factors. It has been found in one investigation that the smoking habits of identical twins are more alike than those of non-identical twins, and other work into the personality characteristics of different types of smokers appears to confirm the view that genotypic differences exist between smokers and non-smokers and between cigarette smokers and pipe smokers.

The Committee has also published the first Supplement to its third research paper, "The Constituents of Tobacco Smoke: an Annotated Bibliography" (which is edited by H. R. Bentley and E. G. N. Berry) $\uparrow$. This useful compilation provides a convenient list of references, arranged in sections corresponding to chemical classes, covering the literature which appeared during 1959 , and will be an invaluable guide to research workers in this field.

W. Carruthers 